\title{
THE COPING STRATEGIES EMPLOYED BY UNISA'S UNDERGRA- DUATE STUDENTS TO ADDRESS THE REALITIES EXPERIENCED WITH RESPECT TO THEIR LIVING CONDITIONS IN SUNNYSIDE, TSHWANE
}

\section{Assim Hashim Alpaslan}

\section{INTRODUCTION AND BACKGROUND TO THE STUDY}

A dearth of information about the realities related to the living conditions of Unisa's undergraduate students in general emerged as a central research problem for an investigation into the realities and coping strategies relating to the living conditions of a sample of Unisa's undergraduate students who reside in Sunnyside, Tshwane.

In a article focussing on the realities related to the living conditions of Unisa's undergraduate students residing in Sunnyside, Tshwane, a word picture depicted the realities experienced by this sample of Unisa's undergraduate students with respect to their living conditions in Sunnyside. They experienced their living conditions to be overcrowded, noisy, unsafe, expensive and unstable (because of constant relocation) and they felt they are exploited by landlords and letting agents. Furthermore, they are confronted with social realities such as xenophobia, crime and violence, drugs, prostitution, street children and beggars. Apart from the realities referred to above (which can be labelled as "challenges"), the participants also mentioned a few benefits of their living conditions in Sunnyside: the proximity to amenities; the ready availability of public transport, and the fact that Sunnyside gives them a sense of connectedness and a place to belong.

In this article the following question, which was formulated at the outset of the study with the aim of specifying the area of interest and focus the study (Maree, 2007:68-69), will be addressed: "What coping strategies are employed by Unisa's undergraduate students residing in Sunnyside, Tshwane to address the realities related to the living conditions?"

\section{RESEARCH METHODOLOGY}

In order to explore and describe the coping strategies employed by Unisa's undergraduate students residing in Sunnyside, Tshwane to address the realities they might face with respect to their living conditions, a qualitative research approach was adopted, since this research aimed to explore, describe and explain people's experiences, behaviours, interactions and social contexts (Fossey, Harvey, McDermott \& Davidson, 2002:717). An explorative, descriptive and contextual strategy of inquiry was pursued within this qualitative paradigm. A nonprobability sampling technique, namely purposive sampling, was used, because the researcher sought participants who were information-rich because of their knowledge and ability to describe the phenomenon under study (Donalek \& Soldwisch, 2004:356). Six $4^{\text {th }}$-level student social workers were engaged as field workers who conducted face-to-face semi-structured interviews with a sample of 24 participants. The central question posed to focus the discussion during the individual (face-to-face) interviews was the following: "How do you cope with the challenges related to your living condition in Sunnyside?" The fieldworkers and the researcher used the eight steps provided by Tesch (in Creswell, 1994:155) to analyse the data systematically. For the purpose of data verification, the researcher employed Guba's model of trustworthiness (as spelt out in Krefting, 1991:215-222).

The next section of this article will present the research findings. 


\section{RESEARCH FINDINGS}

The discussion on the research findings will be presented under the following sub-headings:

- the geographical context where the fieldwork was conducted;

- biographical information of the participants; and

- a thematic discussion on the main theme and sub-themes that emerged from the process of data analysis and the consensus discussion supported by narratives from the transcribed interviews: coping strategies employed by participants to address the realities experienced in relation to their living conditions in Sunnyside, Tshwane.

\section{GEOGRAPHICAL CONTEXT OF THE FIELDWORK}

The fieldwork was conducted in Sunnyside, an inner-city suburb of the City of Tshwane, Pretoria. Sunnyside has the highest percentage of residential units amongst the suburbs of the inner city and lies between Reitz Street and Park Road, Jameson and Kirkness Streets, Nelson Mandela Boulevard and Kotzé and Jeppe Streets. Sunnyside consists mainly of residential houses, high-density areas with blocks of flats and the business centre (Donaldson, Jürgens \& Bahr, 2003:23; Schenck, 2008:2).

\section{BIOGRAPHICAL INFORMATION OF THE PARTICIPANTS}

The majority of participants (23 out of 24) in the sample were black Africans. This phenomenon typifies Unisa's student profile: according to Unisa's HEMIS figures for 2008 found on Unisa's Intranet, $64.6 \%$ of the undergraduate and occasional students registered at Unisa were from the black African culture groups. With reference to the participants' countries and provinces of origin, it emerged that eight participants migrated from elsewhere in Africa to South Africa; this trend is confirmed by figures found on Unisa's Intranet, which indicates that in 2008 there were 20097 individuals from Africa enrolled as undergraduate or occasional students at Unisa (Unisa's HEMIS Figures for 2008). Of the remaining 16 participants, 12 were originally from the Limpopo province. Thirteen of the participants were female and 11 male. The youngest participant was 18 years of age, while the eldest informed the fieldworker that he was 57 years old.

\section{THEMATIC DISCUSSION: COPING STRATEGIES EMPLOYED BY PARTICIPANTS TO ADDRESS THE REALITIES EXPERIENCED IN RELATION TO THEIR LIVING CONDITIONS IN SUNNYSIDE, TSHWANE}

According to the Oxford English Dictionary (1989), "coping" can be defined as "the action or process of overcoming a problem or a difficulty". It can also be viewed as an attribute "designating an activity or mental process, usually unconscious that enables a person to function in or manage stressful conditions or situations" (Oxford English Dictionary, 1989). This section of this article presents the coping strategies employed by the participants to address the realities experienced in relation to their living conditions in Sunnyside.

- Sub-theme: Coping strategies employed by the participants to address the financial difficulties experienced as a result of their living conditions in Sunnyside

The interviews showed that participants employed the following coping strategies (i.e. actions or processes/resources) to address the financial difficulties they experienced: (1) walking instead of using public transport; (2) obtaining employment; (3) constant relocation within the area; (4) sub-letting; (5) engaging in prostitution as a means of survival; and (6) financial support from relatives and boyfriends. Each of these is presented as a category and storylines 
from the transcribed interviews will be provided to support each of the aforementioned strategies.

\section{Category 1: Walking instead of using public transport}

In order to deal with her financial constraints one participant stated: "it is just safe money, if [I] walk."

"We walk... we just have to survive, we walk everywhere."

\section{Category 2: Obtaining employment}

Doing a part-time job was one of the coping strategies used by one participant to help generate additional income. She stated: "Yes. I am doing part-time in the saloon. That's what I do and I am managing with that".

\section{Category 3: Constant relocation within the area}

The following remark by one participant specifically gave rise to this category: "Every month students come and go, come and go ... meaning if they come, [they] stay for a month or two. Depending on the circumstances. If [they] can't afford to pay the rent, [they] move out. It is not like those people come and go ... [it's more] like if they can't manage to pay flat, [they] go at end of the month". Two other participants echoed this by saying: "As I told you, people move around a lot. This happens especially when they owe a lot of rent", and: "If you come to Sunnyside at the end of every month you will see people walking around with their belongings, moving again".

The fact that the students go home for the summer holidays (November until February) feeds into the phenomenon of relocation, since they cannot afford to pay for the accommodation if they are not staying there. One participant explained: "So you normally move a lot if you live in Sunnyside. The ... reason ... is you cannot secure a flat. I need to go home in December, January and February. We cannot afford to pay for my rent during that time. I therefore lose my flat every year at that time".

Apart from constant relocation as a means to deal with debt incurred for not being able to pay for accommodation, participants had to move as "the lease expired and the owner of the flat was not planning to renew the lease, so we had to move". Steep and constant increases in rental amounts also forced a participant to move: "when we went in [i.e. moved into the flat] the rent was $R 2800$, but then it increased rapidly in the beginning of the year to $R 3400$... we moved [as] my brother got a new place not as expensive". "When my brother lost his job, we had to move to another place" was another reason for relocation in Sunnyside. The following reason was also given for the relocation of a participant: "my friend started to work and she had gotten her own place. We thought 'ag, let's break away from the group' as we were seven initially and now we were three in a two-bedroom flat". Another participant provided the following explanation for why she moved out of a flat she shared with fellow flatmates after six months: "When I arrived in Sunnyside in 2004 I lived with complete strangers. This is a very difficult thing. You do not know the people you live with. They might be students at Unisa or other universities. Or they might be saying they are students. One of my biggest problems has been the association. You might not know what your flatmates do for a living or where they get their money. Sometimes you live with drug dealers or prostitutes. The problem is, if they get into trouble, then you are associated with them and you can be affected. This was my experience, so I moved out from this flat after six months". If one looks at the reasons for relocation provided above, they confirm Jones, Siraj-Blatchford and Ashcroft's (1997:48-49) findings that students' 
personal and interpersonal experiences and the choice of suitable and affordable accommodation influence their relocation patterns.

One participant experienced this constant relocation as "very much stressful. You wanna settle; you wanna have one place where people identify you with, where Unisa can send you letters. You wanna have one place which is close to the university. Most probably close to other university facilities. Safe. So, if doesn't work in one place, sometimes you have to move. No notice, you have to move out. Maybe the building has been sold, so you have to move out. Sometimes you don't have necessary amount of money to do that. You have to pause on your studies and to focus on moving out. So you move out, [it] takes you day or two or three to focus again. You have to get used to new place, new people. Raise enough trust at least. Again you are studying. All somehow influence. You find yourself putting on more pressure, more sacrifice than you would have took than if you were living in a relatively better place".

In confirmation of this trend (i.e. relocating because of rent increases) Huchzermeyer (2004:39) quotes Amis, who states that households have to make many compromises when under pressure to pay the high rentals that are typical in South Africa. One such compromise is to relocate or to sublet (see the category below).

\section{Category 4: Sub-letting}

With reference to sub-letting, Simon (2001:295) states that in order for tenants to pay the high rentals, they began taking in sub-tenants. The following quotations from the transcribed interviews confirm this coping mechanism, but also indicate the challenges experienced by one participant in relation to sub-letting:

"People in Sunnyside make business of flats. One would get a flat and then put people in different rooms and then charge them more than he's paying. So he ends up paying nothing and you end up by paying everything".

"I live in a two-bedroomed flat. I have guys in the other room who are sharing with me. And I use the bedroom with my kids... It's R2 800 per month. Sometimes I have no choice [referring to the fact that she is sub-letting to men] because like the rent that I charge for a room it's a little bit high and it's like men can pay that kind of money. That's why I chose to stay with them, but there is nothing that I can do. They are paying R1 800 for the room. No, they are paying $R 900$ each... My electricity bills are almost R600 every month".

"I am living in a two-bedroom flat. I am sharing with another lady and in the other bedroom there are two guys who are sharing in there. Although it is convenient for me to share my flat with other people, in a way it is difficult, in the sense that I don't know the kind of the people, their personalities are. I don't know them." The participant further elaborated and informed the fieldworker that she found herself in a predicament as the lifestyle of the two guys she was subletting to was unacceptable to her: "I only discover when I am already staying with them... in the other bedroom; there are two guys who are staying there. I realised that they are gays when I was staying with them already. It's so inconveniencing to me, because it's not according to my culture and according to my religion, it's unacceptable ... it's something that is weird and I don't believe in that." She also had to learn to tolerate the cultural practices1 in relation to preparing food exercised by "another lady [staying] in the dining room. She has got her a daughter and they come from Ghana and when sometimes they prepare their cultural

1 The fieldworker stated that the participant told her that the meat must rot before it can be cooked 
food it's very smelly and uncomfortable for us because the type of food they eat ... we are not used to it. I find it difficult; sometimes I have to go outside for her to prepare the food, because I cannot stand the smell. It's too heavy for me".

\section{Category 5: Engaging in prostitution as a means of survival}

Although none of the participants were directly involved in prostitution, one of the participants mentioned that her friends turned to prostitution as a way of meeting their financial needs: "It is not that they stand on street corners. When we go to the shops to buy food or to a takeaway place, they will start talking to men. Every time they find someone who is willing to pay. I call them 'Mr Airtime' or 'Mr Clothing Account'... They do not bring these men to our flat, but they go with them to their places or in their cars. This is what they are doing to get the money to pay for what they need." Walker, Reid and Cornell (2004:23) confirm the reality of this scenario when they state that for some women prostitution is a desperate way of survival and for others a method of acquiring certain commodities.

\section{Category 6: Financial support from relatives and boyfriends}

Support from relatives emerged as a financial coping strategy. The following remarks confirm this:

"I'm here on bursary from my government which is paying my fees, any amounts and everything, so my friend is here and is supported by her family. The mother and the brothers they send money for her."

"Sometimes I bump into my uncle and he can give me money - use that money for something else ... I can go and buy some jeans - expensive jeans - can have one or two jeans that I can be like the other students." He worked according to a budget: "this money I can use for this - from here I will use that money, then I know how much I get."

"My mother found a job as a teacher ... My mother can only afford to help me with a certain amount of money. I need to budget to pay for rent, food, airtime and saving to go home at the end of the year."

"My mom sends me money and my dad sends me money."

Even though one of the participants felt betrayed by the boyfriend when she found out that he was a married man, he supported her and helped her to cope with financial difficulties. She told the fieldworker: "When I started this lecturer was taking care of me. Like my rent, taking care of the kids and all the money that I needed he would give me".

"Basically I would say I have a boyfriend who is helping me here and there".

- Sub-theme: Coping strategies employed by participants to deal with the noise levels in Sunnyside

The storylines below indicate how the participants deal with noise as both a reality and a challenge.

"...the noise I am not able to do anything about". This participant does not indicate that she has any coping mechanism in place other than accepting it as a reality beyond her control. Accepting that which one cannot change can be viewed as a coping mechanism in itself.

"You get used to it [i.e. the noise]. I can study with the noise ... [if I want to study] I go to the bedroom". Another participant has grown accustomed to the high noise levels as his coping 
mechanism and stated: "Ag, you know once you have stayed in Sunnyside you get used to it [referring to the noise]".

Another participant copes by closing his door: "if you close your door you don't really hear everything". Another uses the following approach as a coping mechanism: "What I normally do... we have this small radio which I get Zambian music which I like. It really helps. At least it prevents me from hearing the other music that I don't want to hear. At least I can hear the nice and quiet music and study, do assignments... Also I'm getting used to it. You get used to it as you go on. You have this assignment and it is now due, you have to do it whether or not there is noise. But it's just at the time when you want it quiet."

Some of the participants remove themselves from the noisy situations and go and study in their workplace, in quiet parks or use the library facilities. The following remarks confirm this:

"Yes, you know study is difficult with all the noise... [My sister] she will go to the workplace, the office where it is quieter to study. It is just me and her here. Like today, all our friends are here doing each other's hair. So we will walk to a library or the Union Buildings and park and study there... [However], things like that are difficult - you always have to think going wherever."

One participant stated that he does not only use the library to study in order to get away from the noise, but that the overcrowded living conditions leave him and fellow students with no option in "finding campus... our home. That's why I use the library facility. Unisa is supposed to be distance. I should be studying at home place. Well, when my home does not give me that environment that is conducive to studying, I will make the library my day-to-day university. From here go home, drop my bags. Go to school again. And just come back at 10 and sleep. It tends to become the ideal life. You realise that Unisa is a long-distance institution but you feel you have no other choice. You come here every day. Whether it rains, it snows. Initially I would come at 8:00-8:30 when there were no maximum people in the library. But now that there are maximum people [so] I have to get here when library opens 7:45 or 8:00 to get a place. If I fail to get here at 8:30, for example, the library will be full and I will end up in queue. You must spend an hour or two or three depending on where you are and three hours you could cover a lot in three hours. [Fieldworker: So it's a waste of time?] Yes, and it's a waste of focus because if I tune my mind to study and the library is full, I cannot go back because if I go back home I won't study because I've tuned my mind. Not mentioning the distraction and all that. So you stay for whole day in library from eight in the morning and work right through ... I have break one or two and then continue to five or six. Go home to cook and then go to Sunnyside till 10. Don't like to use the facilities [i.e. referring to the library] during the day because very much populated. Crowded. People are not serious down there. Lots of $1^{\text {st }}$ years. Lots of girlsbecomes like fashion show. Everyone comes to show their nice dresses. People answer cell phones in class. People move up and down. How can I study? You feel that I'm just gonna come here at night when there's nobody. Most of time in the evening people comes from work and study. More mature, more sense of seriousness".

"I can say it's difficult to study inside that place [referring to the place where he is staying in Sunnyside]. That is why I am saying that I am going to Sunnyside library at night. Every day at eight in the morning until three or four [he goes to the Unisa library]. After five or six, I come back to library at Sunnyside... Sometimes after eight there will be a queue. Sometimes have to wait until one or two [hours] to get space ... There will be a long queue... I have waited till two and by two I don't think you can manage to study after staying in the queue for four to five 
hours ... it happened once last year. I came here late at around nine and wanted to use the library and it was full. I had to stand in the queue. So now I will wake up early in the morning and then I will be ready around seven".

- Sub-theme: Coping strategies employed by the participants to deal with the crime and violence experienced as a result of their living conditions in Sunnyside

One of the realities experienced in relation to living in Sunnyside, Tshwane is being exposed to violence and crime, either as victims or witnesses. In this section storylines are presented to indicate what coping strategies are employed to address violence and crime.

One participant employed the following practical tips to keep her safe from crime and not becoming a victim of crime again: "My ID I hide and keep safe ... I also ensure that I am never at the flat alone. So if someone comes to rob us again then I am not alone".

Another participant advised: "you do not walk alone". Another participant added: "if you are moving around at night, leave your cell phone at home - don't carry too much around with you". Another confirmed this and stated: "When I go out-especially things like cell phones ... I leave it behind. [I] go with friends, come back together." In order to avoid becoming a victim of violence and crime, one of the participants shared the following with the fieldworker: "you have to check out and look out to see someone suspicious. You cannot carry a bag ... I am mostly just aware of them, most of the drug dealers are very friendly, so then I am just friendly back. You just cope because you cannot control them (drug dealers). It is okay, if I do not mingle".

The only white participant who participated in this study shared with the fieldworker the following in terms of the coping strategies he uses to deal with the reality of crime and violence in Sunnyside: "I've seen Sunnypark people feel safer ... people go there, but they won't walk down the streets ... Esselen Street is no go ... especially at night. That's what I do ... straight from work, I go home ... I'm in my flat until the sun comes up. I am not going to be risking walking around at night. It's something that people miss ... people stayed here, they say they could go out at night ... do window shopping ... whatever ... now they cannot. Especially myself, being alone ... I wouldn't risk going out at night ... definitely not. Whatever I need will have to wait for the morning. I make sure I have everything I need. Those are some of the obstacles. [My freedom, mobility] it's been squished... but even going to central Pretoria is risky ... always you have to be looking over your shoulder ... who is around you - who is next to you ... Being alert. I think after a while you get used to it ... I've got used to it. I actually prefer Pretoria to Johannesburg ... I stayed in Johannesburg before ... but I prefer Pretoria even with all the risks. People are more open - down to earth ... it's a different atmosphere a different vibe. I stayed in JHB South - La Rochelle or Rosettenville. Even there it's risky ... but more risky than here. There I was robbed and stabbed ... here I've almost been robbed twice. I've already got that ... I don't know, once you have been robbed you get like an instinct ... I am more reactive now ... when I sense something is going to happen ... then I cross the street or turn to face them and say: 'What are you up too? Get away from me' ... or whatever. I've become more reactive ... survivor skills ... It does change you ... you become more alert, aware of who is around you, what's going on. Whereas people, some people, they just walk, they don't care who is around them, whereas me, I am always aware of who is around me, behind me ... next to me. Because I am white and walking alone ... you do become a target, especially the guys who pretend to help people park cars ... they are in communication with each other so they will be quick to point out, 'hey that guy'...”. 
One of the foreign students residing in Sunnyside indicated the following coping strategies not to fall prey to a xenophobic attack: "Just like a true foreigner here, I am very careful when I interact with them [i.e. South African citizens]. If I have to interact, I do it, if I don't have to, I don't. I keep away and stay on my own. That has been the situation so far." Later on he remarked: "the keyword is, "keep away where you not wanted"'. Another foreign participant safeguards herself as follows from the possibility of a xenophobic attack: "so much that I normally do want to go outside especially after six pm. I don't want to go outside. I would rather remain inside for my security".

Two of the participants elaborated on the security measures in place where they are renting. Although these are not participants' coping strategies per se, I have included these storylines since they are measures implemented with a view to preventing tenants and owners becoming victims of crime:

"Well, every person who stays there gets a key for the gate. If you have visitors coming they have to organise with you to meet them downstairs. He [the security guard] won't open the gate for them. There is also a register that visitors have to sign when they come in. ... that guard is on duty from 5 pm until 11 pm-after 11 they go, but anyone who comes in to visit between 5 and 11 has to sign in the register and whatever. But I think it's also in terms of preventing overcrowding in the flats. If I have someone sleeping over - a friend - then if that person has signed in the register and hasn't left before $11 \mathrm{pm}$ - they charge me R20 for the person to stay over ... so I have to make sure whoever is visiting me has to leave by $11 \mathrm{pm}$. Definitely. I am happy with the arrangement because it's good".

"You come to my place and then you must phone me and I need the security tag ... I have to come down to see you and you sign in at security ... they don't open ... I come down with tag and then I write you in for the day or if you want to sleep over that must also be arranged by the building manager".

- Sub-theme: Support networks (i.e. family, friends and the church) as coping strategies employed by the participants to address the realities and challenges of living conditions in Sunnyside

Whittaker and Garbarino (1983:5) define the concept of a "social support network" as "a set of interconnected relationships among a group of people that provides patterns of nurturance and provides contingent reinforcement for efforts to cope with life on a day-to-day basis". Support networks can be seen as the relational structure through which people request support and make demands. Support networks can be formal or informal, large or small, short or long term, and the support received can help people cope, simply because they have a variety of people (e.g. family, friends, tutors and lecturers) to turn to, which can be a countermeasure against isolation and depression (Building Support Networks, n.d.). The support networks identified in this research include friends, family and the church.

"I get to see my folks pretty often ... whenever I want to actually". As far as friends are concerned, this participant plays soccer for a local club and described his relations with fellow members as good: "when you play with others in a team you have to have a good relationship with them, so it helps to have a relationship with them off the pitch as well".

One participant referred to the fact that his parents were deceased. He has a support network of friends all over the Tshwane metropolitan area "who really understand me and support me". He mentioned that his friends (who are from the white culture group) don't want to come into Sunnyside and thus he ends up travelling to them. He also received support from work: 
“colleagues from work are supportive and understanding”. He is Catholic and attends Mass in Sunnyside and said about this: "Over weekends I am always doing something, the church keeps me busy". The one participant who was quoted above as saying "keep away where you not wanted" also spoke about the church being his biggest support network: "The only way I can ease my tension and relax myself, where I can get sanctuary, is the church very close to me. So I just go from home to church, back to school where I teach these young children ... back to church and back to home like that. So I actually revolve between my home, my church, and school where I teach...The only place where I feel wanted and I get my sanctuary is at the church. That is why most of the time if I am not at home, you will find me at the church".

"On weekends I do come across my friends and we just chill there and have fun". The other residents of the flat are his cousins and they support each other. They have a good relationship: "so if there is something, we sit as a family and try and analyse what the problem is and try and overcome". Their relationship is one of respect. The negative side of living with his cousins is "if I have done something bad, they see my parents often ... so they can tell my parents". His parents are also supportive and have seen his flat. This is a positive point for him and he remarked that "they know the circumstances".

"You see, in my culture we help each other out. I am the eldest child. My mother is helping me with my studies. I will again help my younger sibling when I qualify and get a job. We are constantly looking out for each other. This motivates me".

"... my friends are here, my sister and I ... church friends and school is here ... communitywise I ensure that I involve myself such as with the church, so cell groups are a very integral part of me" (a reference to another participant's support networks).

One participant who shares a room with his friend in a flat where the owner of the flat and his family stay stated: "We are living as a family ... It feels good because it is like Nelspruit and I don't miss so much."

While the above storylines spoke of participants' support networks, one participant (a foreigner) mentioned the fact that "it is too far from our [referring also to her friend whom she is sharing a flat with] families ... I have no family here". Later on she stated: "in South Africa ... sometimes you feel lonely ... [I] fear to get a friend, especially South African”. Another foreign participant made reference to the challenge he experience in terms of his family support systems: "I've not yet gone home since I'm here. The last 7 years. That's why I'm saying it's a challenge. That support is somehow difficult, because you just phone calls, e-mails, you talk but most probably if you were around or if they were around, you could have boosted something different."

- Sub-theme: Religion as a coping resource employed by the participants to address the realities and challenges experienced in relation to their living conditions in Sunnyside

Nelson (2009:32) postulates that religious motivation impacts on coping. He adds that "Individuals with intrinsic motivation tend to see difficult situations not just as threats but also as opportunities for growth".

The following storylines support this choice of a sub-theme:

"The thing that I can say makes me the strongest to overcome all my obstacles is my strong religious beliefs. I am a Christian and have a close relationship with God ... I can just say that I am coping in my own way by making my own decisions in line with my Christianity." 
In responding to the question on how the participant coped with the challenges experienced in relation to living in Sunnyside, she stated: "God keeps me going".

- Sub-theme: Being focused (i.e. having a goal in mind), being disciplined and making sacrifices as coping strategies in order to stay focused on their studies amidst the realities and challenges of living conditions in Sunnyside

The following quotations bear witness to the participants' coping strategies (i.e. being selfdisciplined, making sacrifices and using self-talk) in terms of keeping focused on their studies amidst the realities and challenges experienced:

"you must tell yourself to get out [i.e. having a focus and be disciplined] ... studying, make sure you pass... so that's what I am doing".

"knowing what you have to achieve ... I have a goal I have to achieve - I will do whatever it takes". This participant is focused on getting his degree and stated that people had to be inspired by something and his inspiration was a car - an Audi RS 6: "I see myself driving the car-it's difficult - you need to know these positive things in life - keep fighting - do whatever it takes".

One participant stated "this is about forcing yourself" when he spoke about his studies and achieving his goal.

"I know my boundaries. I know my goals. I have made it a point to stand strong".

"studies are important ... if friends phone me and say they are on their way or outside my door I answer and say: 'I am not there'... I am working towards my future and the future of my family".

"get[ting] out in two or three years time. Passing [at Unisa] means you open opportunities for yourself”.

"I must study ... if friends come and visit - tomorrow I must work harder".

“[Being disciplined] ... that's what one needs to do to pass Unisa. When you start and study on your own, there is no one to tell you what is right/wrong. So you've got a make more time for yourself to understand it. Major challenge. You've got to do it. Then you have exam to pass. It's not as if assignments count. Here just exams. You have to make sure that you understand, because if you miss that exam, come back in six months. You can't just pay more money. More rent, another module. Everyone just wants to get out. Finish. Get a proper job".

The following quotation illustrates how the participant used self-talk to keep him focused and motivated. He says to himself: "Yes, I have conquered it. I have conquered Unisa. Some people are still there doing the $10^{\text {th }}$ year in Sunnyside in that very tumultuous environment. You are strong $R$, you can do it. That's the message I'm busy saying to myself. Well, there still much to come, but you've succeeded so well. Safe, alive 'cause one can get out of Sunnyside dead you know. Alive, safe! There's something to celebrate and be happy".

"Ja, to be focused you have to study. If you are not a hard worker things will not go well for you ... Because there is no full-time classes like other institutions: you attend every day ... there will be lecturers and they will be showing you the way and doing everything for you. But here at Unisa they will be giving you assignments, tutorial letters. If I can do this thing well, I can manage to pass. Other students are not used to that. They are coming from secondary school. There is always a teacher in front of you. They are used to teachers teaching you everything. Here it is not like that. That is why students are dropping out." 


\section{"You just need to work hard."}

"But I know I had to change my life, had to adjust, discipline myself. I had to sacrifice. I had to say 'no' to certain things. They do not know exactly how I got these things right. They think; 'Oh this kid is smart'. It's not about being smart. There are many other variables of life that you've got to play right to get out ... I feel very much good and can't wait to finish. Yes, move on 'cause again one must not think of staying in Sunnyside. No one enjoys. Just have to cross through. That's all I did. Unfortunately people so short-sighted that Sunnyside is life for them."

These remarks tie in with Kobasa's construct of "hardiness" (in Van Breda, 2001:40), which refers to commitment and which results, in turn, in a sense of purpose that can carry a person through difficult times. It is "hardiness" that enables individuals to be in control over what is happening around them; part of this quality involves the belief that the impact of life events is a result of one's own reactions and attitudes to life. Furthermore, "change" is viewed as a normal occurrence in life and stressful events are not a cause for dismay or surprise.

\section{CONCLUSIONS AND RECOMMENDATIONS FOR FURTHER AND FUTURE RESEARCH}

The above research findings describe the coping strategies employed by a sample of Unisa's undergraduate students to address the realities (i.e. challenges) they experience in relation to their living conditions in Sunnyside, Tshwane. Based on the research findings and the literature verification, the following conclusion can be drawn.

It seems that various coping strategies are adopted to help the participants deal with the realities and challenges experienced with respect to their living conditions in Sunnyside. As far as financial difficulties are concerned, participants resorted to the following coping strategies: walking instead of using public transport; obtaining employment to generate income; constantly relocating within the area; sub-letting in order to meet financial demands; engaging in prostitution as a means of survival; and receiving financial support from relatives and boyfriends. Coping strategies used to deal with the noise included: accepting the noise as being part and parcel of the reality of staying in Sunnyside; removing themselves from the noisy situations by going to their workplace, quiet parks or a library to study; and simply getting accustomed to the noise. In dealing with the crime and violence that is so rife in Sunnyside, the participants became "streetwise" by not walking alone at night, staying indoors, not carrying valuables (i.e. cell phones, large amounts of money) and a preference for apartments where tenants' and owner's security are seen as a priority. Furthermore, the researcher came to the conclusion that the participants turn to family, friends, the church and religious belief as support networks in helping them to deal with the realities and the challenges they encounter as a result of living conditions in Sunnyside. From their remarks the researcher also came to the conclusion that staying focused, self-discipline and making sacrifices were used as coping strategies to help the participants remain focused on their studies.

\section{RECOMMENDATIONS FOR FUTURE RESEARCH}

- That this research project be replicated using a sample of white, coloured and Indian undergraduate students residing in the area investigated (since only one participant from the white population group was included in the sample and none from the coloured and Indian population groups);

- That a research project be undertaken to explore and describe the coping strategies related to the living conditions of Unisa's postgraduate students who reside in Sunnyside; 
- That this research project be replicated in the other cities where Unisa has regional offices (i.e. Cape Town, Johannesburg, Polokwane, Bloemfontein and Durban);

- That a survey be conducted to find out the number of undergraduate students from residential universities residing in Sunnyside, and to undertake a research project to explore the realities and coping strategies of those who reside in Sunnyside, Tshwane;

- That a comparative study be undertaken to compare the realities and coping strategies related to the living conditions of Unisa's undergraduate students with those who are registered at residential universities (and who reside in Sunnyside);

- That a research project be undertaken to identify (i.e. explore and describe) the nature of support needed by Unisa's undergraduate students residing in Sunnyside and their perceptions of Unisa's role in addressing these needs.

\section{REFERENCES}

BUILDING SUPPORT NETWORKS. n.d. [Online] Available: http:// www.studentsdepression.org [Accessed: 29/07/2009].

CRESWELL, J.W. 1994. Research design: qualitative and quantitative approaches. Thousand Oaks, Calif: Sage Publications.

DONALEK, J.G. \& SOLDWISCH, S. 2004. Demystifying nursing research: an introduction to qualitative research methods. Urologic Nursing, 24(4):354-356.

DONALDSON, R., JÜRGENS, U. \& BAHR, J. 2003. Inner-city change in Pretoria: social and spatial trends. Acta Academia Supplementum, 1:1-33.

FOSSEY, E., HARVEY, C., McDERMOTT, F. \& DAVIDSON, L. 2002. Understanding and evaluating qualitative research. Australian and New Zealand Journal of Psychiatry, 36:717732.

HUCHZERMEYER, M. 2004. Unlawful occupation: informal settlements and urban policy in South Africa. Trenton, NJ: Africa World Press.

JONES, M., SIRA-BLATCHFORD, J. \& ASHCROFT, K. 1997. Researching into student learning and support in colleges and universities. London: Routledge.

KREFTING, L. 1991. Rigor in qualitative research: the assessment of trustworthiness. The American Journal of Occupational Therapy, 45(3):214-222.

MAREE, K. 2007. First steps in research. Pretoria: Van Schaik Publishers.

NELSON, J.M. 2009. Psychology, religion and spirituality. New York: Springer.

OXFORD ENGLISH DICTIONARY. 1989. ( $2^{\text {nd }}$ ed). [Online] Available: http://dictionary.oed. com/cgi/enty_header/50049724?case_id=hLNy-DdrJwV-5589 [Accessed: 22/09/2009].

SCHENCK, C.J. 2008. Report on the Sunnyside awareness walk: Tutorial Letter 101 of 2008 for Module SCK305B/WFS305Q. Pretoria: Unisa.

SIMON, D. 2001. Equitable and sustainable urban futures in post-apartheid Southern Africa. In: DE WET, C.J. \& FOX, R.C. (eds) Transforming settlement in southern Africa. Edinburgh: University Press.

UNISA HEMIS figures for 2008. Retrieved from Unisa Information and Analysis Portal. [Online] Available: http://heda.unisa.ac.za/heda/fsMain.htm [Accessed: 25/09/2009]. 
VAN BREDA, A.D. 2001. Resilience theory: a literature review. Pretoria: Military Psychological Institute.

WALKER, L, REID, G. \& CORNELL, M. 2004. Waiting to happen: HIV/AIDS in South Africa: the bigger picture. Cape Town: Juta.

WHITTAKER, J.K. \& GARBARINO, J. 1983. Informal helping in human services. New York: Aldine de Gruyter.

Dr Assim Hashim Alpaslan, Department of Social Work, University of South Africa, Pretoria, South Africa. 